KAROL TOEPLITZ

Chrześcijańska Akademia Teologiczna w Warszawie

\title{
Chrześcijaństwo pozakonfesjonalne i Søren Kierkegaard
}

„Nawet gdyby równocześnie żyjące pokolenie nie pozostawiło w spadku nic innego poza słowami: «Wierzyliśmy, że tego to a tego roku ten Bóg ukazał się nam w postaci poniżonego sługi, żył wśród nas i nauczał, a następnie zmarł» - wystarczyłoby to w zupełności, by wierzyć”1. I dalej: „Pokolenie żyjące równocześnie z Nim zrobiło wszystko, by to małe ogłoszenie, to historyczne nota bene wystarczyło, by stać się pobudką dla wszystkich później żyjących; najściślejszy przekaz nie może nigdy stać się niczym więcej dla późniejszych ludzi”.

Właściwie na tym cytacie i komentarzach Duńczyka doń, można by było referat zakończyć. Dlaczego? Zawarte w tej myśli przesłanie sytuuje refleksję myśliciela jednoznacznie poza obrębem zinstytucjonalizowanego chrześcijaństwa, z wszystkimi elementami charakteryzującymi Kościoły, i to niezależnie od konfesji. Czego w tak pojętym myśleniu o chrześcijaństwie brak? Mnóstwa czynników, np.: Pisma Świętego (!), hierarchii, dogmatyki, sakramentów, merytorycznych treści etycznych (tak ważnych szczególnie po Immanuelu Kancie), będących cechą wszystkich Kościołów, a także doświadczeń historycznych Kościołów chrześcijańskich, konkretnych tekstów konfesji (np. Confessio Augustana), orzeczeń soborów (przykładowo z Nicei), pism zwierzchników danego Kościoła itd. Banalne wydaje się stwierdzenie, że konfesje są zwerbalizowanym i zwięzłym wyrazem tożsamości danego Kościoła ${ }^{2}$. Dla Kierkegaarda formalnie wiążąca definicja Kościoła zawarta jest w Konfesji augsburskiej: „Kościół jest zgromadzeniem świętych, w którym się wiernie

${ }^{1}$ S. Kierkegaard, Okruchy filozoficzne. Chwila, thum. K. Toeplitz, Warszawa 1988', s. 127; Kęty $2011^{2}$, s. 148 .

2 Por. K. Toeplitz, O tożsamości konfesyjnej, cz. I, „Myśl Protestancka” 3 (1999), s. 20-36; cz. II, „Myśl Protestancka” 4 (1999), s. 32-43. 
naucza Ewangelii i należycie udziela sakramentów"3. Dotychczasowych wywodów Kierkegaarda w żaden sposób nie da się, jak widać, pogodzić z credo luteranizmu ${ }^{4}$.

Powstaje teraz niebagatelny problem: Jak uzasadnić ciągłość historyczną chrześcijaństwa? Myśliciel odpowiada: dokonuje się to dzięki subiektywnemu zapośredniczeniu! Ponadto: idzie tu o wiarygodność przekazu człowieka żyjącego równocześnie. Mówiąc językiem filozofa: „Tymi ludźmi są tak zwani uczniowie z drugiej ręki”.

Jedyne, co mogą oni zrobić dla późniejszych pokoleń, to stać się pobudką. Można się zastanawiać nad tym, czy to oznacza, że wiara późniejszych ludzi „wisi na czymś tak kruchym, jak świadectwo sprzed dwóch tysięcy lat”. Oznacza to, że w przekazywanej wierze zawarty jest moment świadectwa (!) i dlatego nie da się jej empirycznie (naukowo) dowieść. $Z$ tego wynika jednoznacznie, że wiara pojedynczego człowieka nie jest dlań wnioskiem, lecz postanowieniem! W rachubę nie mogą wchodzić żadne argumenty racjonalne, jak wnioskowania sylogistyczne itp. Klasycznym przykładem tych wątków jest Abraham z Bojaźni i drżenia ${ }^{5}$, a dodatkowo wpisuje się ten typ myślenia w alternatywę wiary i rozumu apostoła Pawła. Zilustruję ten wątek cytatem z Okruchów filozoficznych ${ }^{6}$. Człowiek w procesie poznania natrafia na coś nieznanego.

Pozwólcie więc to nieznane nazwać Bogiem. To jest tylko miano, które Mu nadajemy. Zechcieć udowadniać, że to nieznane (Bóg) istnieje, nie powinno rozumowi zapewne przyjść na myśl. Mianowicie, o ile Bóg nie istnieje - niemożliwością jest dowiedzenie Jego istnienia, ale jeśli jest, to byłoby głupotą chcieć to udowadniać, w tym bowiem momencie, w którym zaczynam tego dowodzić, założyłem Jego istnienie i to nie jako wątpliwe... lecz jako to, co ustalone, gdyż w innym przypadku w ogóle bym nie zaczynał i łatwo zauważyć, że całość wywodu byłaby bezsensowna, gdyby Jego nie było. Jeśli natomiast używając wyrażenia: „udowodnić istnienie Boga" sądzę, że udowadniam, iż to, co nieznane, które istnieje jest Bogiem - wówczas wyrażam się w sposób mniej udany; nie udowadniam wówczas niczego, a w najmniejszym stopniu - jakiegoś istnienia, lecz rozwijam definicję pojęcia ${ }^{7}$.

3 Wyznanie augsburskie (Konfesja augsburska), VII, O Kościele, w: Księgi wyznaniowe Kościoła luterańskiego, tłum. A. Wantuła, J. Jackowski, W. Niemczyk, J. Pośpiech, Bielsko-Biała 1999, s. 144.

${ }^{4}$ Nieprzypadkowo cytowana tu książka była ostatnią, która w domu Kierkegaarda czy biskupa Mynstera była przedmiotem ich konsultacji i dialogu. Duchowny słusznie uznał, że poglądy myśliciela noszą ewidentnie znamiona herezji, a zawarte tam tezy były kolejnym już kluczem (po Bojaźni i drżeniu) do całej późniejszej twórczości teologo-filozofa.

${ }^{5}$ Zob. K. Toeplitz, Konflikt Abrahama (Próba egzystencjalizacji religii prawa), „Gdańskie Zeszyty Humanistyczne" 2 (1966), s. 29-71.

6 S. Kierkegaard, Okruchy filozoficzne...; por. wyd. II, s. 89-90.

7 Tamże. 
Mówiąc inaczej: albo (rozum), albo (wiara). Tę alternatywę wyrażało już dwutomowe dzieło pod tym właśnie tytułem.

Rodzi się pytanie: Która konfesja może sobie pozwolić na rezygnację $\mathrm{z}$ używania rozumu w celu uzasadniania swoich treści dogmatycznych? Retoryczne pytanie, ale to jednocześnie oznacza, że wiara każdego człowieka jest w pełni uprawniona!

Wracam do przerwanego wątku. Powyższe oznacza także, że treść przekazywana jest też tylko przedmiotem wiary - stwierdza Kierkegaard. Ponadto jest dlań oczywiste, że to, co posiadł „uczeń z pierwszej ręki”, też otrzymał on od samego Boga! Wieńczy ten wywód następująca myśl: „Tylko ten, kto sam otrzyma niezbędny warunek od tego Boga, tylko ten wierzy”!!! A rola Kościoła, chciałoby się zapytać?! Instytucja jest w tym przypadku jedynie przeszkodą w ukształtowaniu się wiary Pojedynczego.

Nie ma się czemu dziwić, albowiem konkretne konfesje traktowane są jako coś obiektywnego (!), co subiektywiście nie mogło odpowiadać. Konfesja augsburska przejęła zresztą pewne cechy charakteryzujące tożsamość Kościoła. Jest to na przykład honorowanie chrztu, wreszcie potępienie herezji i świadectwo męczenników.

Mówiąc najprościej: w kwestii stania się wierzącym ws zy s c y pośrednicy zostają wykluczeni, więc wszystkie propozycje wiary są równouprawnione! Wzmacnia to Kierkegaard cytatem z 1 Listu do Tymoteusza $(2,5)$ : „Albowiem jeden jest Bóg, jeden też pośrednik między Bogiem a ludźmi, człowiek Chrystus Jezus".

Ta ponadkonfesjonalna koncepcja mogłaby się współcześnie stać fundamentem ekumenii, gdyby nie dzielące Kościoły różnice dogmatyczne i zaszłości historyczne.

Jeżeli czytam, że w Kościele Rzymskokatolickim, na kanwie I Soboru Watykańskiego w encyklice Mystici Corporis z 1869/1870, uznano za ważne podkreślenie tożsamości empirycznej hierarchów z ciałem Chrystusa, to oczywiście podobna deklaracja dogmatyczna dzieli Kościoły chrześcijańskie, a nie zbliża do siebie.

Jest jasne, że dla Kościołów zinstytucjonalizowanych obowiązuje starożytna norma: Ubi ecclesia, ibi spiritus sanctus Dei, et ubi spiritus dei, illic ecclesia et omnis gratia. Rudolf Bultmann, i nie on jeden, głosi, że „,...] nie ma wiary w Chrystusa, która jednocześnie nie byłaby wiarą w Kościół jako nosiciela kerygmatu"8. Wniosek tego myśliciela jest, w świetle wywodów Kierkegaarda, daleki od oczywistości, gdyż zgodnie z jego poglądami właśnie

${ }^{8}$ Por. R. Bultmann, Das Verhältnis der urchristlichen Christusbotschaft zum historischen Jesus, Bonn 1961, s. 26. 
Kościół może być, albo nawet jest, zaprzeczeniem chrystianizmu, a uznanie Mesjasza nie powoduje automatycznie uhonorowania Kościoła.

Duńczykowi chodziło o uwolnienie wiary od wszelkich możliwych „,domieszek", na przykład racjonalnych, zgodnie z poglądami apostoła Pawła, wreszcie o uwolnienie spod racjonalnej filozofii, teologii i masowej praktyki kościelnej. Wspólnota religijna $\mathrm{z}$ tego punktu widzenia staje się zagrożeniem dla niepowtarzalności podmiotowej, w szczególności grozi brakiem subiektywnego wysiłku, zaangażowania, uwewnętrznienia (!). Już z tego powodu krytykuje Kierkegaard pojmowanie Kościoła w luteranizmie. Wrogiem autentycznej wiary nie staje się agnostycyzm czy ateizm, czy nawet romantyczne pojmowanie wiary, lecz struktury instytucjonalne Kościołów. Tak więc „,z powrotem do jednostki!", do Pojedynczego, specyficznej kategorii w myśli Duńczyka. Indywidualizacja wiary musi się dokonać za sprawą samej jednostki, jej decyzji, natomiast czynniki zewnętrzne należy traktować jako zagrożenie dla autentyzmu wiary.

O różnych odcieniach wiary, typach, cechach charakterystycznych, wariantach, w sposób przekonujący pisał niedawno Jacek A. Prokopski ${ }^{9}$. Istotne jest jedno: Kierkegaardowi cały czas chodzi o maksymalne religijne dobro Pojedynczego. I, dodajmy, jest on w tym wysiłku skazany wyłącznie na siebie. Duńczyk nie osiągnął jasności w kwestii pojmowania wiary jako indywidualnego wysiłku i zarazem d a ru łaski. Nie znalazłem w jego piśmiennictwie na temat tych relacji żadnej przekonującej wzmianki.

Podobnie jest z jeszcze jednym problemem: Jak się ma zindywidualizowana wiara do Pisma Świętego? Przytoczony na samym wstępie cytat o Piśmie Świętym nie wspomina, a przecież Kierkegaard nieustannie doń się odnosi..., chociaż z zastrzeżeniami. Był on w pełni świadomy niezliczonych sprzeczności zawartych w całej Biblii ${ }^{10}$. Ten wątek w teologii średniowiecznej i późniejszej stał się czymś oczywistym od czasu opublikowania dzieła Piotra Abelarda Sic et non. Od czasów Abelarda po Kierkegaarda bibliści dotarli do olbrzymiej liczby świadomych lub nieświadomych przeinaczeń oryginalnych tekstów biblijnych w trakcie ich thumaczenia ${ }^{11}$. Zadanie „Pojedynczego” sprowadzało się do tego, by sprzeczności rozstrzygać samemu, bez pomocy jakiejkolwiek

9 J.A. Prokopski, Paul Tillich - odwaga wiary w wieku zwątpienia, „Nowa Krytyka” 36 (2016), s. 75-92.

10 Por. K. Toeplitz, Czy sprzeczności moga mieć budująy charakter, „Słupskie Studia Filozoficzne" 4 (2002), s. 5-20; tenże, O immanentnych sprzecznościach w Biblii, w: Filozofia dialog - uniwersalizm. Ksiegga dedykowana prof. J. Kuczyńskiemu, red. J.L. Krakowiak, W. Lorenc, A. Miś, Warszawa 2001, s. 67-77.

${ }^{11}$ Por. w tej kwestii chociażby: Status błędu w filozofii i teologii, red. L. Miodoński, Wrocław 2014, szczególnie artykuł S. Stasiaka, Btędy w przekazie tekstu biblijnego, s. 59-68 i B. Ferdka, Błąd teologiczny a ekumenizm, s. 155-170. 
teologii czy Urzędu Nauczycielskiego - to miał być jeden z elementów autentycznej wiary właśnie.

Jaka jest więc rola Biblii w kształtowaniu się wiary, szczególnie Nowego Testamentu? Syntetycznie opisuje to nasz autor w Nienaukowym zamykajacym „post scriptum” do „Okruchów filozoficznych"12. Immanentne sprzeczności występujące w Biblii to zadania stawiane każdemu, pro me, to sprawdziany wiary właśnie. Według Duńczyka wskazówki (i tylko tyle) zawarte w Piśmie Świętym należy zinternalizować, przyswoić sobie i zdwoić, zreduplikować, subiektywnie (!) przetworzyć w ży ciu, w sobie. Autor książki analizuje dwa warianty.

Oto pierwszy. Jeśli udało się krytykom Pisma uzasadnić swoje poglądy, to: ,[...] nigdy nie można wyjść poza aproksymację i $[\ldots]$ między nią i osobistym nieskończenie wielkim zainteresowaniem własnym wiecznym zbawieniem zachodzi istotna sprzeczność"13. Jeżeli bada się Pismo jako pewny (!?) punkt oparcia, analizuje przynależność poszczególnych pism do kanonu, ich autentyczność, ich integralny charakter, wiarygodność autora, wreszcie ustanawia się dogmatyczną gwarancję pod postacią inspiracji kanonu, to należy odnotować, że we wszystkich tych poczynaniach występuje, jak pisze Kierkegaard, pewna niejednoznaczność! Oczekiwanie, że z tych wywodów wyniknie cokolwiek dla wiary, jest złudzeniem. Nie można na Piśmie Świętym budować swojego wiecznego zbawienia. W dodatku, kto zakładał w tych wywodach inspirację, musi każdy krytyczny głos uznać za wyraz wątpliwości, za pokusę, a ktoś, kto zagłębi się w tok wywodów krytycznej teologii, nie będzie mógł wydedukować z tego, co napisano w Piśmie, inspiracji. Sama inspiracja jest przedmiotem wiary, a więc jest niedowodliwa! Każdy Pojedynczy dostrzeże tu brak gotowego rezultatu, będąc jako żywo i z całą żarliwością zainteresowany swoim wiecznym zbawieniem. „Samo zakwestionowanie przez Lutra Listu do Jakuba wystarczy, by doprowadzić go do rozpaczy"14. Ponieważ wszystkie badania historyczne mają niezakończony charakter, niepodobna decyzji dotyczącej zbawienia wiecznego odkładać do czasu zakończenia procesu badawczego. Rzecz jasna, spory ściśle filologiczne da się rozstrzygać, ale nie te są najważniejsze, skoro najistotniejsze jest znalezienie drogi do wiecznego zbawienia.

Jeżeli więc napotkamy teologa, który, jak sądzi, wykazał dowodnie autentyzm ksiąg - jednostka winna zrezygnować z wszelkich naukowych wtrętów. „Tak więc zakładając, że wszystko, co dotyczy Pisma jest w porządku - co da-

12 S. Kierkegaard, Nienaukowe zamykajace „post scriptum” do „Okruchów filozoficznych”, tłum., wstęp, komentarze K. Toeplitz, Kęty 2011.

13 Tamże, s. 44.

14 Tamże, s. 46. 
lej? Czy wówczas człowiek pozbawiony wiary przybliżył się do wiary choćby o jeden krok? Nie. Ani o jeden" ${ }^{15}$. Można by zapytać, dlaczego? Dlatego, że przy takim obiektywnym podejściu traci się nieskończenie silne i żarliwe zainteresowanie wiecznym zbawieniem... Pojedynczy będzie potrzebował wiele „bojaźni i drżenia”, aby wejść na prawdziwą ścieżkę wiary. „Jeśli się bowiem zabierze żarliwość towarzyszącą pożądaniu zbawienia, nie ma już wiary"16. Nawet gdyby, powiada nasz autor, zeszli się wszyscy aniołowie, i tak mogliby wydać tylko aproksymację, a to za mało, by na niej zbudować swoje, subiektywne zbawienie.

Oto druga możliwość. Załóżmy, że wrogom udało się udowodnić wszystko, co tylko możliwe, by obalić autorytet Biblii. To znaczy wykażą, że Księgi nie są nienaruszone, nie są autentyczne, ich zestaw jest w wysokim stopniu umowny, nie mówiąc już o wątpliwościach dotyczących inspiracji itd. Co wtedy? Otóż z tego wszystkiego nie wynika, że ci autorzy nie istnieli i przede wszystkim, że Chrystus nie istniał. Kierkegaard konsekwentnie akcentuje, że wiara (idzie o drogę do zbawienia) i dowód się wykluczają. Podsumowując, można powiedzieć:

Chrześcijaństwo jest duchem, duch jest wewnętrznością [w człowieku], wewnętrzność jest subiektywnością, subiektywność jest z istoty swojej żarliwością, w swoim maksimum jest nieskończenie osobiście zainteresowaną żarliwością pożądania swojego wiecznego zbawienia. Jeśli tylko zrezygnuje się z wewnętrzności, a z subiektywności wyeliminuje żarliwość pożądania, a z niego nieskończone zainteresowanie - wówczas w ogóle nie może być mowy o podjęciu decyzji ${ }^{17}$.

Za subiektywnością jako priorytetem w kwestiach wiary przemawiają także odpowiednie cytaty z Nowego Testamentu. I takie spotykamy u Duńczyka wielokrotnie. Przykładowo w Ewangelii Mateusza $(4,6)$ czytamy: „Ale gdy się modlisz wejdź do komory swojej, a zamknąwszy drzwi za sobą, módl się do Ojca swego, który jest w ukryciu... a Ojciec twój odpłaci tobie"; i rada: „Aby Chrystus przez wiarę mieszkał w sercach waszych” (Ef 3,17). I wreszcie zapewne rozstrzygająca wskazówka-konstatacja: ,[...] albowiem oto królestwo Boże wewnątrz was jest” (Łk 17,21) i podobna myśl: ,[...] wyznawajcie, że Bóg jest prawdziwie w was" (1 Kor 14,25). Jeżeli uzna się trafność tych wypowiedzi, wówczas każde zewnętrzne świadectwo o Bogu równie dobrze może być złudzeniem. Deprecjonuje to także tak zwane obiektywne dowody przemawiające na rzecz wiary. Jednostka w sobie musi znaleźć podstawy swojej wiary.

\footnotetext{
15 S. Kierkegaard, Nienaukowe zamykajace „post scriptum”..., s. 49.

16 Tamże.

17 Tamże, s. 52.
} 
Reasumując, można powiedzieć - zgodnie z tezą wyjściową, w której odnotowano jedynie wiarę w obecność Chrystusa na Ziemi, Jego nauczanie, cierpienie i śmierć, a brakuje wskazówki dotyczącej znaczenia Biblii - że jej rola zostaje uznana za niewystarczające źródło wiary. I nie pomogą tu argumenty pro et contra. Jeżeli subiektywizm wiary ma dać wierzącemu nadzieję (i tylko) na wieczne zbawienie, i to dzięki olbrzymiej żarliwości, zaangażowaniu - to Pismo Święte może, z powodu aproksymacji, stać się jedynie wtórnym (!) czynnikiem, będącym rezultatem dodatkowego wyboru kształtującego postawę chrześcijanina. Taką rolę w biografii Kierkegaarda ono odegrało. Wspomina on zresztą o tym, że przez praktycznie ponad dwa wieki obchodziło się chrześcijaństwo bez Pisma Świętego, a na jego rzecz optowali apostołowie, męczennicy i świadkowie, którzy swoim życiem pisali historię. (Ten ostatni wątek zresztą w dalszej analizie wróci). Dodajmy, że liczne sprzeczności występujące w Biblii Kierkegaard traktuje jako wiarotwórcze (!), gdyż zmuszają one jednostkę do wewnętrznego wysiłku w celu zajęcia wobec nich stanowiska.

W tym kontekście zasygnalizuję jeszcze jeden problem. Skoro na aproksymacji związanej z Biblią nie można jej w sposób powszechnie dostępny i zrozumiały uznać za podstawę wiary chrześcijańskiej, choćby ze względu na subiektywne quodlibet, a publikacje Kierkegaarda były dogłębnie analizowane, więc pojawiła się propozycja zbudowania tej wiary na instytucji Kościoła ${ }^{18}$. To był specyficznie duński pomysł, funkcjonujący zresztą po dziś dzień.

Według Kierkegaarda nie tylko katolicki Kościół stwarzał wał ochronny przeciwko wtargnięciu do doktryny dialektyki. „Również protestantyzm, gdy zrezygnowano z Biblii jako trwałego oparcia, próbował stworzyć coś podobnego do instytucji Kościoła"19 i to był pomysł Grundtviga, który trafnie zauważył, że Biblia nie może się skutecznie oprzeć narastającym wątpliwościom, ale nie dostrzegł tego, że zarówno atak, jak i obrona opierały się na aproksymacji. Tak jak przedtem Biblia miała rozstrzygać, co jest chrześcijańskie, a co nie, tak teraz taką funkcję miał spełniać Kościół jako obiektywny (?) i pewny autorytet. Jednak określenie, że jest on „chrześcijański”, oznacza więcej niż tylko to, że jest współczesny, i to zbliża tę ideę do trudności, które dotyczyły Biblii, mimo że stała się ,żywym słowem” głoszonym „tu i teraz”.

Zilustrujmy to przykładem. Swego czasu pojawił się problem, który zwrot jest prawdziwy: „Wierzę w chrześcijański Kościół” czy „Wierzę, że istnieje chrześcijański Kościół”? Rozstrzygnięcie wymaga odwołania się do historii, a więc wchodzenia na drogę aproksymacji. Według Duńczyka, kto wyznaje „obiektywne chrześcijaństwo”, np. pod postacią Kościoła, jest poganinem. Dalej słusznie zauważa, że zanim powstała Biblia, chrześcijaństwo reprezen-

18 A. Broń-Wojciechowska, N.F.S. Grundtvig, Warszawa 1986, s. 54-67.

19 S. Kierkegaard, Nienaukowe zamykające ,post scriptum”..., s. 54-55. 
towali ustnie apostołowie. Z kolei fakt, że chrześcijaństwo przetrwało 1800 lat, nie może być argumentem, albowiem islam też już istnieje 1200 lat. Nawet 3000 lat istnienia nie mogłyby świadczyć o chrześcijańskości Kościoła. Argument dotyczący sceptyka Kierkegaard formułuje następująco: „Czy jesteś na tyle zuchwały, by zaprzeczyć prawdzie? Czy masz prawo uroić sobie, że niezliczone pokolenia, miliony milionów, żyły w błędzie ${ }^{20}$. Potem następuje w wywodach interesujący wątek psychologiczny, kiedy autor pyta:

Czy ty, nędzny, pojedynczy człowieku masz prawo do tego, by zgubić te miliony milionów, ba, poniekąd całą ludzkość? Popatrz, wstają z grobów; popatrz, zobacz w swojej wyobraźni pokolenie za pokoleniem, a są to wszystko ci wierzący, którzy w prawdzie chrześcijaństwa znaleźli spoczynek... ci wierzący będą osądzać ciebie, ty bezczelny buntowniku... Ty zostaniesz stracony, hen do świata ciemności, oddalonego od raju, do którego oni weszli. [...] Osiemnaście stuleci powinno właśnie wzbudzać przestrach. Jako dowód pro są one w momencie wyboru dla podmiotu zerem; jako straszak contra są wyśmienite ${ }^{21}$.

Kończąc ten ważny wątek, Duńczyk zauważa, że Kościół wygładza kanty osobowości, przekreśla niepowtarzalność, przejmuje inicjatywę dokonania wyboru, dodatkowo gwarantując przynależność do chrześcijaństwa „czarno na białym" pod postacią odpowiedniego dokumentu.

Samo chrześcijaństwo akcentuje nadzwyczaj silnie rolę podmiotu, pojedynczego człowieka i chce mieć do czynienia tylko z nim, wyłącznie z nim, z każdym $\mathrm{z}$ nich z osobna. Dlatego niechrześcijańskim nadużyciem ze strony osiemnastu stuleci jest zwabianie jednostki do chrześcijaństwa argumentem osiemnastu wieków jego istnienia, albo wtłaczanie jej tam strachem - ona tam w ten sposób i tak nie wejdzie ${ }^{22}$. Sapienti sat.

Subiektywizm, w myśl tezy „prawda jest subiektywnością” - oczywiście, prawda wiary - musi wywołać egzystencjalne napięcia; nikt nigdy nie może mieć pewności, że „odczytał” przeciwieństwa w sposób poprawny. Wszystko to musi w konsekwencji prowadzić do niepowtarzalności podmiotowej, do egzystencji odmiennej aniżeli „się” żyje. Konsekwencją tego musi się stać antagonizm „Pojedynczego” (Den Elkente) i społeczeństwa, jego powszechne potępienie. Ten proces musi być równoznaczny z samooczyszczeniem się z konfesjonalnych i społecznych wartości. Z nich bowiem dla kształtowania się wiary nic nie wynika...

\footnotetext{
20 S. Kierkegaard, Nienaukowe zamykające „post scriptum”..., s. 66.

21 Tamże.

22 Tamże, s. 67.
} 
W kontekście całokształtu wywodów Duńczyka niezbędne jest ponowne przywołanie tu następującego wersetu: „Albowiem jeden jest Bóg, jeden też pośrednik między Bogiem a ludźmi, człowiek Chrystus Jezus" (1 Tm 2,5). A ponieważ, jak powiedziano wyżej, jest On wewnątrz pojedynczego człowieka, jest zsubiektywizowany, wynika z tego cała krytyka zinstytucjonalizowanego chrześcijaństwa i podkreślenie egzystencjalnego charakteru wiary. Stąd Kierkegaard wielokrotnie odwołuje się do Nowego Testamentu, w którym rzeczywiście wielokrotnie przywołuje się alternatywę: albo Bóg i wiara, albo dobra tego świata (np. J 4,4, Łk 6,26; 1 J 2,15 itp.). W radykalnej postaci mamy wypowiedź Jezusa o tym, że jeżeli człowiek pragnie osiągnąć niebo, powinien sprzedać wszystko, co ma, rozdać ubogim (por. Mk 10,21) i naśladować Go. Duńczyk osądza nie tylko współczesny mu świat chrześcijański $\mathrm{z}$ tego powodu, że zaniechał naśladownictwa, ale - poza pierwotnym chrześcijaństwem - całą jego historię. Nie ma więc podstaw, aby ludzie mówili, że są chrześcijanami. I jest to wina Kościołów, także reformacji, która zamiast utrudnić stawanie się nimi, jeszcze to ułatwiła.

Ciekawostką warsztatową Kierkegaarda jest to, że dla uzasadniania swoich propozycji posługuje się różnymi gatunkami literackimi. I tak, mamy obszerne dialogi, beletryzację najpoważniejszych problemów, parodie, eksperymenty literackie, satyry, pseudonimowość, humoreski, wreszcie ironię, a wszystko po to, by człowiekowi maksymalnie utrudnić stanie się osobą wierzącą, w ostateczności chrześcijaninem ${ }^{23}$. W sprawach ironii wzorem dlań był nie tylko Sokrates, któremu poświęcił swoją pracę doktorską, ale także przede wszystkim Gotthold Lessing ${ }^{24}$. Ten unikał apodyktycznych wypowiedzi, był powściągliwy w swoich krytykach, ,przekonał” Kierkegaarda, że niepowtarzalności nie da się nauczać, i wreszcie, że tzw. prawdy historyczne nie prowadzą do wiecznej prawdy i w takich przypadkach musi nastąpić ,skok”, postanowienie, decyzja, wybór albo - mówiąc językiem początków chrześcijaństwa - „herezja”, ale bez negatywnej komponenty, którą to pojęcie z biegiem czasu nabrało. Stąd też autentycznie wierzący może być przez społeczeństwo nie tylko nie zrozumiany, ale i potępiony; ideałem będą tu męczennicy. Jest taka praktyka według Kierkegaarda „skokiem do wolności”, zgodnie ze wskazówką zawartą w Liście do Galacjan.

W kontekście tytułu tego tekstu istotnym problemem jest zagadnienie komunikacji międzyludzkiej, mającej sprzyjać „skokowi” do wiary. Jak mają się ze sobą komunikować, np. uczeń z pierwszej ręki albo późniejsi z Pojedynczym w XIX wieku? Ograniczę się w tym miejscu do cytatu w przekładzie

${ }^{23}$ Pod adresem Lutra Kierkegaard sformułuje zarzut, że ten maksymalnie ułatwił (!) stanie się osobą wierzącą, o czym jeszcze niżej napiszę.

${ }^{24}$ S. Kierkegaard, Nienaukowe zamykajace „,post scriptum”..., s. 79-133. 
Antoniego Szweda, w powszechnie znanej nomenklaturze kierkegaardologicznej: „Po chrześcijańsku wiara jest u siebie, w tym, co egzystencjalne - Bóg nie wystąpił w charakterze docenta, posiadającego kilka naukowych twierdzeń, w które najpierw należy uwierzyć, a potem zrozumieć".

Nie, „wiara” jest u siebie i ma swoje miejsce w tym, co egzystencjalne, przez całą zaś wieczność nie ma do czynienia z wiedzą i nie dostarcza wyższego i najwyższego stopnia wiedzy. Wiara jest wyrażeniem stosunku osobowości do osobowości. Osobowość nie jest sumą naukowych twierdzeń, osobowość jest skierowana ku bezpośredniej dostępności, to najskrytsza świątynia, coś tajemniczego, sekretnego; osobowość jest w tym, co wewnątrz, dzięki czemu słowo persona (personare) znaczy „w sobie” (wewnątrz), do czego sama osobowość musi się ustosunkować w wierze. Pomiędzy osobowością i osobowością żaden inny związek nie jest możliwy.

Weźmy dwoje namiętnie kochających się ludzi, którzy byli, jak się powiada, jedną duszą w dwóch ciałach - nigdy nie można wyjść poza wiarę, że drugi kocha. W tym czysto osobowym związku pomiędzy Bogiem, który jest osobowością i wierzącym jako e gzy stuj ąc ą osobowością występuje pojęcie wiary... Dlatego posłuszeństwo wiary (Rz 1,5) jest wyrażeniem apostolskim, i w ten sposób wiara jest zorientowana ku woli, osobowości, nie ku intelektowi ${ }^{25}$.

Ten obszerny cytat wskazuje jednoznacznie, że wiara jest nie tylko czymś zegzystencjalizowanym, ściśle wewnętrznym, tajemniczym itp. Jak może ona się stać pobudką?

Żaden wniosek indukcyjny nie spowoduje, że ten „wzorzec” wiary, to znaczy „uczeń z pierwszej ręki”, stanie się rzeczywiście wzorcem godnym naśladowania, przyczyniając się do rozpowszechnienia chrześcijaństwa. Zakomunikowana tajemnica ex definitione przestaje być tajemnicą, czymś wewnętrznym. Mówiąc inaczej: osobowość jest niekomunikowalna, zwłaszcza bez wypaczeń! Nie da się z tajemnicy cechującej osobowość, z jej niepowtarzalności, opracować uniwersalnej, ponadkonfesyjnej, propozycji religijnej albo właśnie dlatego jest ona możliwa. Stąd też powstają wątpliwości dotyczące możliwości bądź niemożliwości istnienia chrześcijańskiego egzystencjalizmu ${ }^{26}$.

Dodajmy jeszcze, że wiara w ujęciu Kierkegaarda musi być rezultatem przetworzenia słów (Jezusa) w czyny. Nie wystarczy znajomość Biblii, żeby być Pojedynczym: „Bądźcie wykonawcami Słowa, a nie tylko słuchaczami oszukującymi samych siebie" (Jk 1,22 i n.); ,[...] nie ci, którzy zakonu słucha-

25 S. Kierkegaard, Dziennik (Wybór), tłum. i wstęp A. Szwed, Lublin 2000.

${ }^{26}$ Por. K. Toeplitz, O możliwości lub niemożliwości istnienia chrześcijańskiego egzystencjali$z m u$, ,Studia Filozoficzne” 7 (1983), s. 3-26. 
ją, są sprawiedliwi u Boga, lecz ci, którzy zakon wypełniają usprawiedliwieni będą" (Rz 2,13). Nacisk położony zostaje nie na znajomość Pisma, lecz na przetworzenie jego wskazań w życie, na nadanie tekstowi Biblii życia, a przez to wzbogacenie wiary Pojedynczego. Chodzi o „uwewnętrznienie” treści tak, by stały się one częścią osobowości. To ich egzystencjalizacja! Na ogół używa się tu także określenia ,interioryzacja”. Dodajmy, że przetworzenie słów w czyny ma subiektywny charakter, to niejako reduplikacja, zdwojenie, powtórzenie, tyle że na płaszczyźnie dającej się zaobserwować. W tym przypadku ujawnia się antagonizm subiektywnej decyzji z obiektywnym porządkiem społecznym.

Mistyka jest konkluzją wynikającą z ostatnich stron tego tekstu, a odegrała ona niebagatelną rolę w czasach reformacji. Duńczyk też nie uchronił się przed nią. Powszechnie uznawana jest doniosłość źródeł mistycznych reformacji, szczególnie rola, jaką tradycje niemieckiej mistyki odegrały w umysłowym przygotowaniu reformy Lutra. Daje się zauważyć, że tendencje mistyczne w łonie Kościołów zarówno luterańskich, jak też reformowanych, spotykały się nie tylko z oporem, ale z gwałtowną krytyką. Przy całym subiektywizmie akcentowanym przez Kierkegaarda nie da się elementów mistycznych ukryć. To właściwie nic nowego. W tradycjach Kościołów poreformacyjnych zawierała się - jak pisze Leszek Kołakowski ${ }^{27}$ - idea interioryzacji i autentyfikacji życia religijnego, pobożności czynnej, której to elementy sprzyjały podatności na wpływy mistyczne. Mamy u Duńczyka wskazówkę ukazującą trwały antagonizm między podstawowymi wartościami chrześcijaństwa a zbiorowością kościelną, z wszystkimi jej atrybutami. Luterskie sola fide et sola gratia, którym to wartościom Duńczyk jest aż nadto wierny, także eliminują ,widzialne pośrednictwo łask niewidzialnych". Zarówno w klasycznej mistyce, jak i u Kierkegaarda widoczna jest negacja kultu zewnętrznego, niezbędnego dla zbawienia, podobnie jak idea niekonieczności ortodoksji ${ }^{28}$. Leszek Kołakowski, dokonując podziału głównych wariantów mistyki, na pierwszym miejscu wskazuje indywidualizm radykalny, zakładający nieprzydatność zasadniczą albo szkodliwość „widzialnych” i kolektywnych form kultu w realizacji wartości religijnych jakichkolwiek, a więc także odmowę celowości reformy Kościołów ${ }^{29}$. Poglądy Kierkegaarda idealnie do tej charakterystyki pasują. To indywidualizm ewangeliczny stawiający sobie za cel zbawienie i praktyczne naśladowanie Chrystusa. To, jak konkluduje Kołakowski, subiektywizm mistyczny!

27 Por. L. Kołakowski, Świadomość religijna i więź kościelna. Studia nad chrześcijaństwem bezwyznaniowym siedemnastego wieku, [szczególnie rozdz. I]. Warszawa 1965.

28 Por. A. Kłoczowski, Drogi i bezdroża. Szkice z filozofii religii dla humanistów, Kraków 2017, s. 35-47.

29 Por. L. Kołakowski, Świadomość religijna i więź kościelna, s. 46. 
W swoich założeniach nie dawała się ta odmiana mistyki ostatecznie uzgodnić, nie tylko z zasadami reformacji zorganizowanej, ale i z propozycją samego Kierkegaarda. Jeśli idea komunikacji bezpośredniej i osobowej, personalnie rozumianej, z Bogiem, jest celem najwyższym jednostki ludzkiej - wówczas zbędne stają się nie tylko sakramenty działające przez struktury zorganizowane Kościołów, ale także same te struktury wraz ze swoimi doktrynami.

Porównajmy to z cytatem rozpoczynającym niniejszy tekst i okaże się, że otwiera się teraz pole dla uniwersalizmu religijnego, pozakonfesjonalnego ${ }^{30}$. Jednak postawy takie są w skali makrospołecznej pozbawione jakichkolwiek perspektyw powodzenia; indywidualizmem nie można - jak uczy historia europejskiej mistyki - podważyć w sposób skuteczny samej instytucji Kościołów, niezależnie od konfesji. Gwoli sprawiedliwości może należy odnotować, że Kościół Rzymskokatolicki potrafił „,spacyfikować” niektóre odłamy mistyki, nawet przejmując od niej szereg postulatów.

Przyjrzyjmy się teraz definicji mistyki zaproponowanej przez L. Kołakowskiego i spróbujmy ją skonfrontować już teraz bardziej szczegółowo z poglądami Duńczyka.

Doktryna, wedle której możliwe jest, w pewnych warunkach, aby dusza ludzka, będąca pewną rzeczywistością różną od ciała ludzkiego, komunikowała się przez doświadczenie [...] z tą rzeczywistością duchową, która zachowuje pierwotność wobec wszelkiej innej rzeczywistości; przyjmuje się zarazem, że komunikacja ta, połączona z intensywnym afektem miłości, a przy tym wolna od udziału fizycznych władz człowieka, stanowi szczególnie pożądane dobro i że jest ona, przynajmniej w swoich formach najintensywniejszych, najwyższym dobrem jakie człowiek może zrealizować w życiu ziemskim ${ }^{31}$.

Oto jeszcze cechy najważniejsze charakteryzujące mistyków. Jest to przekonanie o integralnym zepsuciu natury ludzkiej. To nadto pogarda dla wiedzy świeckiej i teologicznej oraz uznanie doświadczenia wewnętrznego za programowo niewyrażalne. Wreszcie jest to idea miłości bezinteresownej w stosunku do jakichkolwiek dóbr doczesnych, a jedyne, co mistyka interesuje, to wieczne zbawienie. Ponadto jest to negacja czasu, zarówno przeszłego, jak i przyszłego, lub uznanie go za wartość subiektywną. Wreszcie mistyk uznaje antagonizm indywidualności i doskonałości, stworzenia i Stwórcy na płaszczyźnie moralnej, który może być zniesiony jedynie w wieczności.

30 Jako pierwszy ideę bezwyznaniowego i pozakościelnego chrześcijaństwa sformułował bodajże Sebastian Franck, i to w opozycji do reformatorskich idei Lutra.

31 L. Kołakowski, Świadomość religijna i więź kościelna, s. 4-26. 
Cechy te, naszkicowane przez Kołakowskiego, idealnie pasują do poglądów Kierkegaarda. Świadczy o tym zarówno jego negacja 18 wieków historii chrześcijaństwa jako argumentu na rzecz wiary, jak też antagonizm jednostki z Kościołem luterańskim w Danii oraz akcentowanie subiektywności poparte cytatami z Nowego Testamentu. Mamy także totalną nieprzydatność tak zwanych „obiektywnych” i kolektywnych form kultu, co zostało wyeksplikowane w 10 ulotkach pt. Chwila ${ }^{32}$. Jest to w końcu propozycja religii wewnętrznej, której pełne znaczenie manifestuje się i nabiera sensu w negacji tzw. chrześcijaństwa obiektywnego. Gdyby go nie było, nie wiadomo by było, na czym polega egzystencjalna prawowierność, czyli to, co umownie (!) można by nazwać ortodoksją; więcej jeszcze, istnienie Kierkegaardowskiego wariantu wiary, swoista herezja, z punktu widzenia kościelnej ortodoksji jest warunkiem istnienia tej ostatniej. Gdyby więc nie istniała ta herezja, choćby przejściowo, należałoby jej zrodzenie zainspirować przez kościelną ortodoksję, dla dobra samej tej ortodoksji!

W gruncie rzeczy mamy u Duńczyka nawoływanie do powrotu do źródeł, to znaczy do gminy pierwotnej, do czasów, kiedy chrześcijaństwo rozprzestrzeniało się poprzez naśladowanie Chrystusa, a więc drogą męczeństwa i cierpienia dla wiary, drogą przykładu osobistego wyznawców, przy braku pisemnego ujęcia poglądów zgodnie z zalecaną formułą jedności: „,prawdy drogi i życia".

Kwintesencją ideału chrześcijanina jest dla Duńczyka „świadek prawdy”. Jego określenie zawdzięczamy polemice filozofo-teologa z przemówieniem nowego biskupa Kościoła duńskiego, profesora Hansa L. Martensena (byłego nauczyciela akademickiego Kierkegaarda) nad grobem biskupa Jakoba P. Mynstera, kiedy to ten ostatni został właśnie tak nazwany. Myśliciel przez czas jakiś wstrzymywał się z polemiką, która wzburzyła już przedtem skandynawskich protestantów. Owa definicja-opis w pełni oddaje ideał Kierkega$\operatorname{arda}^{33}$. Otóż autor pisze, że świadek prawdy nigdy nie zaznał przyjemności, a jedynie cierpienia:

Świadek prawdy to człowiek, który w nędzy świadczy na rzecz prawdy, jest znienawidzony, poniżany, jest najpośledniejszy w swojej znikomości, ponadto zapoznany, znienawidzony, wyszydzany, wykpiwany, wyśmiewany - a i chleb

$32 \mathrm{~W}$ Polsce ulotki te, z których 10. ukazała się już po śmierci autora, wydane zostały dwukrotnie: por. S. Kierkegaard, Okruchy filozoficzne. Chwila, tłum. K. Toeplitz, Warszawa 19881; Kęty $2011^{2}$.

${ }^{33}$ Zob. S. Kierkegaard, Czy biskup Mynster byt „świadkiem prawdy”, jednym z „,prawdziwych świadków prawdy” i czy jest to prawda??, tłum. K. Toeplitz, „Kronos” 1 (2016), s. 223-227. S. Kierkegaard, Czy biskup Mynster byt ,"świadkiem prawdy”, jednym z ,prawdziwych świadków prawdy” i czy jest to prawdą?, w: tenże, Pisma późne, thum. i komentarze K. Toeplitz, Kęty 2016, s. 350-357. 
powszedni nie zawsze widział codziennie, taki był biedny, ale chleb codzienny prześladowań był mu dany dzień w dzień w wystarczających ilościach... Świadek prawdy, jeden z autentycznych świadków prawdy, to człowiek torturowany, poniewierany, przenoszony $\mathrm{z}$ jednego więzienia do drugiego i na koniec - to było jego ostatnie wywyższenie, dzięki któremu został przyjęty do pierwszej klasy chrześcijan, do grona autentycznych świadków prawdy, by wreszcie - ponieważ jest to jeden z prawdziwych świadków prawdy [...] - wreszcie zostać ukrzyżowanym albo zdekapitowanym, albo spalonym, albo zostać upieczonym na ruszcie, a jego pozbawione ducha ciało zostaje przez oprawców rzucone w jakieś odległe miejsce, pozostaje niepochowane: tak się chowa świadków prawdy! - albo spala się je na popiół, a jego resztki zostają rozproszone przez wiatr, aby wszelki ślad tego ,ścierwa", jak to powiada apostol ${ }^{34}$, zostało unicestwione, jak śmiecie tego świata ${ }^{35}$.

Mamy więc ideał chrześcijanina, postać niezależną od kraju pochodzenia, w pełni odpowiadającą wymogom pierwotnego chrześcijaństwa do czasów wstępnego spisywania tekstów, które potem weszły do kanonu Nowego Testamentu, wreszcie postać odpowiadającą prześladowaniom czasów dokonstantyńskich. A jak to widział autor tego tekstu w odniesieniu do siebie? ${ }^{36}$ Søren Kierkegaard wielokrotnie w swoich pismach powoływał się na zawarty w różnych miejscach Nowego Testamentu Jezusowy postulat naśladownictwa. Myślał nawet o tym, że władze go w końcu aresztują, ale ku jego rozczarowaniu wcale tego nie zamierzano. Natomiast Nikolaj Frederick Severin Grundtvig swojemu religijnemu sceptycyzmowi nadał charakter instytucjonalny, powołując do istnienia samodzielny Kościół, o czym wspominałem już wyżej.

Zróbmy teraz wstępny bilans przedstawionych treści. I tak według Kierkegaarda, istniejącego świata quasi-chrześcijańskiego nie należy wcale reformować czy poddawać krytyce pochodzącej z zewnątrz. Stąd niejednokrotnie będzie się odwoływał do Marcina Lutra, chociaż i wobec niego będzie krytyczny, szczególnie z powodu immanentnej sekularyzacji wiary w następstwie reformacji, jej dążenia do wyeliminowania cierpienia jako atrybutu wiary i zastąpienia go instytucją, mającą być gwarantem autentyczności wiary, przy jednoczesnym eliminowaniu „bojaźni i drżenia” jako konstytutywnego elementu wiary. Za swoistych prekursorów mógł uznać przykładowo Piotra Waldensa, głoszącego kult ubóstwa, także tłumaczącego Biblię w taki sposób, aby ją

341 Kor 4, 13 [przyp. S. Kierkegaarda].

35 S. Kierkegaard, Czy biskup Mynster byt ,'świadkiem prawdy”, jednym z „prawdziwych świadków prawdy" i czy jest to prawdą?, w: tenże, Pisma późne, s. 353.

${ }^{36}$ Por. K. Toeplitz, Wiara Sørena albo dlaczego Kierkegaard nie mógt się przyznać do bycia chrześcijaninem, w: W kręgu Kierkegaarda, red. A. Szwed, Kęty-Warszawa 2014, s. 3-12; K. Toeplitz, Dlaczego Kierkegaard nie mógł uznać siebie za chrześcijanina, w: S. Kierkegaard, Pisma mniejsze (wybór) w thumaczeniu Karola Toeplitza, Toruń 2007, s. 5-10; K. Toeplitz, O możliwości lub niemożliwości istnienia chrześcijańskiego egzystencjalizmu. 
przybliżyć ludziom. Podobnie zresztą uczynił później Jan Hus. Jednak to oddzielne tematy.

Odrzuca Duńczyk celowość analiz i uwag krytycznych wobec świata chrześcijańskiego prowadzonych niejako z zewnątrz, przykładowo przez Bruna Bauera, Ludwiga Feuerbacha, Immanuela Kanta, nie mówiąc już o Georgu W.F. Heglu, zwłaszcza jego koncepcji mediacji przeciwieństw. Pod uwagę należałoby wziąć liczne grono myślicieli, którzy wywarli wpływ na Kierkegaarda, w tym Davida F. Straußa czy przykładowo Artura Schopenhauera.

Naszemu bohaterowi bliżej, co zabrzmi może paradoksalnie, do angielskiego deizmu czy niemieckiego oświecenia. Nie dziwi powtarzające się nawiązywanie do G.E. Lessinga, a i poglądy Daniela Schleiermachera też nie mogły mu być obojętne. Ten bowiem przeniósł religię ze sfery racjonalnej do sfery uczucia, emocji, wyobrażenia i chociaż Duńczyk nie zgadzał się z nim, za trafne uznał jednak samo przeniesienie ciężaru wiary do sfery indywidualnej, do subiektywności, chociaż odmiennie rozumianej; również postulat autonomizacji religii miał tu swoje znaczenie. Johann G. Hamann, Frederik Christian Sibbern, Poul M. Møller, Johan L. Heiberg i wspomniani wyżej biskupi Martensen i Mynster, wreszcie poeta Hans C. Andersen. Wszyscy myśliciele, którzy akcentowali podmiotowość człowieka, przeciwstawiając ją tzw. porządkom obiektywnym, znaleźli się w kręgu zainteresowań Kierkegaarda.

Duńczyk z uznaniem wyrażał się o sekularyzacji zakonu krzyżackiego w 1525 roku jako o kroku zmierzającym do oddzielenia Kościoła od państwa. Nie wolno przy tym zapominać, że na skutek wydarzeń Wiosny Ludów w 1848 roku doszło w Danii do autonomizacji Kościoła. Król przestał być zwierzchnikiem Kościoła, a ten uzyskał swoistą autonomię. Kierkegaard już wcześniej zainteresował się poglądami współczesnego mu teologa Andreasa Gottloba Rudelbacha, krytykującego oficjalne, czyli państwowe pojmowanie chrześcijaństwa. Pod tym względem było obu po drodze. Zewnętrzna manifestacja wiary, jako modelu bycia chrześcijaninem, została przez Duńczyka odrzucona. Cały czas szło mu o gruntowną wewnętrzną przemianę Pojedynczego, o metanoie, co miało uniwersalny, ponadczasowy charakter, a zarazem uwalniało państwo od ideologiczno-religijnych komponentów. Jeśli idzie o przemiany wewnętrzne zachodzące $w$ ludziach, to droga do pozakościelnego chrześcijaństwa wiodła od krytycyzmu wobec instytucji kościelnej, od sceptycyzmu, ewentualnie deizmu i poprzez agnostycyzm nawet do ateizmu. Krytyka instytucjonalnego działania Kościołów miała podstawy nie tylko w odejściu od wskazań Biblii, ale w narastaniu podmiotowości wierzących. Sprzyjały temu przemiany cywilizacyjne, wzrost wiedzy o nie zawsze chwalebnej historii Kościołów (np. inkwizycji, wojnach chłopskich w Niemczech XVI w.), wreszcie polifonia kościelna występująca w obrębie świata chrześcijańskiego i przeświadczenie, że żaden Kościół nie ma monopolu prawdy wiary. 
Katolicki teolog o. Andrzej Kłoczowski $\mathrm{OP}^{37}$ widzi ten problem następująco. Istnieją $\mathrm{d} w \mathrm{a}$ nurty współczesnego polskiego katolicyzmu. $\mathrm{Z}$ jednej strony mamy trend zmierzający do umacniania istniejących struktur kościelnych, przepisów oraz tradycji połączony z ignorowaniem krytyki dostojników kościelnych czy hierarchów, z obrońcami status quo w obliczu mało ortodoksyjnych publikacji ukazujących się nawet na łamach czasopism katolickich, z drugiej mamy do czynienia z rosnącą liczbą świeckich teologów, ruchami kościelnymi skupiającymi ludzi świeckich (ok. 3 miliony osób). Drugi nurt, przybierający na sile, nie jest wprawdzie nastawiony na niszczenie Kościoła instytucjonalnego, ale znajduje posłuch i zwolenników na marginesie samego Kościoła. To m.in. ruchy typu ,szkoła wiary”, ruchy wyrażające niezadowolenie z powodu niedostosowywania się instytucji do zmieniających się wymogów rzeczywistości, do nieuzasadnionego unikania problemów, z którymi cywilizacja zachodnia nie miała dotychczas do czynienia, a przed którymi stają wierni, i to coraz częściej (eutanazji, aborcji, małżeństw księży itp.). Nowe oczekiwania są przez pierwszy tu wymieniony nurt krytykowane i tłamszone. Tymczasem rozrastająca się liczebnie grupa zautonomizowanych chrześcijan wywołuje narastający opór wobec tradycyjnie konserwatywnych tendencji występujących w Kościołach silnie zinstytucjonalizowanych.

Dodać w tym kontekście należy, że odchodzenie od Kościołów, które wyrosły na bazie reformacji, jest znacznie większe aniżeli od Kościoła Rzymskokatolickiego i od prawosławia, co jest następstwem tego, że reformacja wykluczyła instytucję kościelną z roli pośrednika między wierzącym a Bogiem, a więc inaczej aniżeli w przypadku dwóch przed chwilą wymienionych Kościołów. Potwierdza to empiria: wystarczy spojrzeć na stan Kościołów w Skandynawii, a i w tradycyjnie katolickiej Bawarii stracił ten Kościół swoją pierwszorzędną rolę i znaczenie.

Co więc charakteryzuje tak zwane chrześcijaństwo pozakościelne, pozainstytucjonalne? Są tu teoretycznie możliwe, ale i praktycznie spotykane, dwa warianty. Z jednej strony przytoczony na samym wstępie, według którego, aby wierzyć, wystarczy, że człowiek przyjmuje, iż w określonym roku Bóg ukazał się ludziom pod postacią poniżonego sługi, żył wśród nas i nauczał, a następnie zmarł. Ten wariant, jak stwierdzono wyżej, niekoniecznie musi mieć szczegółowe (!) chrześcijańskie aspiracje. Drugi natomiast wiąże powyższy wybór z koniecznością przyjęcia, akceptacji i przetwarzania ${ }^{38} \mathrm{w}$ życie wskazań Biblii ${ }^{39}$, w szczególności Nowego Testamentu, ale odrzuca wszelkie insty-

${ }^{37}$ Por. J.A. Kłoczowski, Leszka Kołakowskiego myślenie o religii. Szkice o filozofii religii dla humanistów, cz. I i II, Kraków 2017.

${ }^{38}$ Zob. niżej różnicę między pojęciem logosu i dawar.

39 Powyższe oznacza, że „Pojedynczy” (Enkelte; niekiedy K. używa określenia: Enkeltperson) przyjmuje tekst wraz z całą dyskusyjną problematyką dotyczącą przykładowo kształtowania się 
tucjonalne interpretacje $\mathrm{e}^{40}$. Niezbędna jest tu niewielka dygresja nie tylko natury semantycznej. Otóż greckie pojęcie logosu oznacza uporządkowywanie, rozsądek, powściągliwość czy umiarkowanie. Tymczasem hebrajskie dawar, w ujęciu Izraelity, oznacza nieustanny ruch; to pojęcie tożsame z pojęciem czynu, to dynamiczna wszechmoc, np. Pana, erupcja Jego mocy. Polski autor ${ }^{41}$ głosi, że pojęcie to oddałoby najtrafniej pojęcie „słow oczyn”. Oznacza to na przykład, że słowo użyte w prologu Ewangelii Jana i w Apokalipsie - to nie logos, to dawar! Manifestuje On swój byt w nieustających czynach, wyrokach czy rozkazach, będących jednocześnie ich wykonaniem. Wybór Biblii musi zatem być jednocześnie przetworzeniem jej treści (np. zaleceń), realizacją praktyczną przyjętego posłania. Tak musiałoby być pojmowane chrześcijaństwo pozakościelne albo - mówiąc inaczej - pozainstytucjonalne.

Przyjmuje więc wierzący człowiek, według tego wariantu, Pismo Święte wraz z wszelkimi problemami, które dotyczą Biblii. Te muszą być indywidualnie rozstrzygane i nikt i nic tego subiektywnego wysiłku nie może zastąpić. $\mathrm{W}$ obu wariantach niekonfesjonalnej wiary znajduje się $\mathrm{z}$ tego powodu element mistyki.

Badania socjologiczne potwierdzają fakt narastania w kulturze śródziemnomorskiej liczby osób wyznających wiarę pozainstytucjonalną. Wiąże się to m.in. z coraz silniejszym oddziaływaniem skutków sekularyzacji (laicyzacja stosunków międzyludzkich) oraz ujawnianiem zarówno historycznych, jak i aktualnych odstępstw poszczególnych Kościołów od chrześcijaństwa, sprzeniewierzanie się formalnie głoszonej doktrynie. W jakim stopniu takie postawy, coraz częściej spotykane, będą oddziaływać na sferę wartości - trudno w tej chwili rozstrzygać. Wydaje się, że istnieje jedna zasadnicza odpowiedź

\footnotetext{
i przyjęcia kanonu, który - jak wiadomo - w różnych Kościołach lokalnych różni się nie tylko co do wielkości; ponadto musi przyjąć nie tylko do wiadomości, ale do zadecydowania, co począć z różniącymi się tłumaczeniami z języka hebrajskiego, greckiego czy łaciny, wreszcie jak rozstrzygać (oczywiście ściśle subiektywnie) występujące w Piśmie sprzeczności. Por. S. Stasiak, Btędy w przekazie tekstu biblijnego, s. 59-68, w: Status blędu w filozofii i teologii, red. B. Ferdek, L. Miodoński, Wrocław 2014. Autorowi idzie zarówno o błędy zawinione świadomie, jak i nieświadomie. To liczne problemy dotyczące autorstwa różnych tekstów, zagadnienia ksiąg wtórnokanonicznych itp. Może spośród licznych problemów wymieńmy jeden. Oto nie tylko w Qumran znajdują się dwa warianty Księgi Jeremiasza, z których jeden jest krótszy aż o 1/8. Podobnie z zabójcą Goliata - mamy dwóch różnych bohaterów tego czynu, a oba znajdują się w kanonie... Niepodobna tu wymienić wszystkich problemów, które dotyczą skutków wyboru Pisma, przed którymi staje wierzący. Instytucja za niego tych problemów nie rozstrzygnie, nie może.

40 Dotyczy to na przykład „wyznań wiary”, które dzielą Kościoły mieszczące się w chrześcijaństwie. Por. Z. Pasek, Wyznania wiar. Protestantyzm, Kraków 1999. Autor prezentuje tam łącznie dokumenty 15 Kościołów protestanckich i mających protestanckie rodowody. Por. także J.A. Kłoczowski, Leszka Kołakowskiego myślenie o religii, w: Drogi i bezdroża. Szkice z filozofii religii dla humanistów, s. 219-227.

${ }^{41}$ Por. R. Brandstaetter, Krag biblijny, Warszawa 1979, s. 74.
} 
na pytanie, w jaki sposób wspomniane pozakościelne postawy będą narastały: dzięki ś wi a d e c twu, o czym była mowa wyżej. Jeżeli poszczególni wierzący znajdują się w tej sytuacji kulturowej, wówczas każdy z nich ponosi wielką odpowiedzialność, gdyż od niego zależy wiara innych ludzi, a nawet przyszłych pokoleń. Świadectwo jest bowiem przekazem prawdy, w którym nie ma przemocy (czy szantażu intelektualnego), nie ma nacisku ze strony struktur zorganizowanych, jest ono swoistym zaproszeniem do uczestniczenia w takich praktykach życiowych, które upodmiotowują człowieka; to zaproszenie do uczestniczenia w doświadczeniu nadającemu ludzkiej egzystencji sens.

Pośród bardziej znanych myślicieli XX w., u których znajdziemy znaczące reperkusje pozainstytucjonalnego chrześcijaństwa, znajduje się przede wszystkim Niemiec Karl Jaspers i niemal nieznany w Polsce Peter Wust ${ }^{42}$.

Oddziaływanie myśli Kierkegaarda w Danii, a właściwie w całej Skandynawii, było olbrzymie. Na zakończenie chciałbym się odwołać do dwóch przykładów. Myśliciel, 2 października roku 1855, padł nieprzytomny na ulicy. Potem okazało się jeszcze, że jego nogi zostały sparaliżowane. Przyjęty do szpitala oznajmił, że jego choroba ma charakter psychiczny i że przybył tu, by umrzeć. Miał więc pełną świadomość swojego położenia. Do pokoju szpitalnego, w którym leżał, zabronił wpuszczać swojego brata, Petera, biskupa Kościoła Ewangelicko-Augsburskiego, podobnie jak dobrze mu znanego redaktora „Fædrelandet”, opiniotwórczej gazety nie tylko w Danii. Dostęp do umierającego mieli kuzyni: Christian i Peter Lundowie, którzy na samym pogrzebie odegrali znamienną rolę. Søren przyjmował także przyjaciela lat młodzieńczych, pastora Emila Bøsena. Jest to w tym kontekście ważna postać. Sporządzał on codziennie notatkę z ostatnich rozmów z myślicielem. Kiedy zaproponował mu spowiedź i komunię świętą, Søren odmówił. Na usilne namowy Bøsena odpowiedział: ,„[... no to umrę bez komunii... Nie chcę na ten temat dyskutować. Dokonałem wyboru. Księża są urzędnikami państwowymi, a państwowi urzędnicy nie mają niczego wspólnego z chrześcijaństwem”. Na kategoryczne pytanie, czy wobec tego umrze bez ostatniej komunii, odrzekł:

„Tak, mogę tak postąpić. Najpierw pomodlę się o odpuszczenie mi wszystkich grzechów. Następnie będę się modlił o to, abym w chwili śmierci być wolny od rozpaczy. Następnie będę się modlił o coś, na czym mi bardzo zależy, żebym odrobinę wcześniej wiedział, kiedy nadejdzie chwila śmierci”. Na pytanie Bøsena

${ }^{42}$ Zob. P. Wust, Niepewność i ryzyko, tłum. i wstęp K. Toeplitz, Warszawa 2006. 
„Czy to jest wszystko czego sobie życzysz; czy to dlatego, że jesteś człowiekiem wierzącym i swoją ostoję masz w łasce Bożej oferowanej przez Chrystusa?" - odparł: „Tak, to oczywiste, jakże mogłoby być inaczej”43

Søren Kierkegaard zmarł 11 listopada, a 18 listopada w katedrze biskupiej odbyło się nabożeństwo żałobne, mimo że kłóciło się to z podstawowym przesłaniem myśliciela. Poza bratem zmarłego Peterem i proboszczem katedry innych duchownych w kościele nie było. Była to niedziela i kościół był przepełniony. W odczuciu tłumów instytucja kościelna zawłaszczała zmarłego! Omal nie doszło do rozruchów, czemu zapobiegli studenci, którzy w zwartym szyku, jeszcze w kościele, otoczyli trumnę. Przemówienie Petera Kierkegaarda było taktowne i ukierunkowane na to, aby wrogość tłumów złagodzić. Natomiast na cmentarzu doszło do skandalu. Głos zabrał, wbrew zwyczajom i przepisom, siostrzeniec zmarłego, Henrik Lund. Zakwestionował on prawo Kościoła do zawłaszczenia osoby zmarłego; powołał się na Listy św. Jana i czwartą Ewangelię, po to, by uzasadnić, iż zmarły miał pełne prawo, opierając się na Nowym Testamencie, uznać siebie za chrześcijanina; dodatkowo powołał się na drugi numer Chwili ${ }^{44}$, szczególnie na podrozdział zatytułowany: „Co Chrystus sądzi o urzędowym chrześcijaństwie”, odwołując się do słów apostoła Łukasza „Tylko czy Syn Człowieczy znajdzie wiarę na ziemi, gdy przyjdzie?" (Łk 18,8).

\section{THE BEYOND-CONFESSIONAL CHRISTIANITY AND SØREN KIERKEGAARD}

\section{Summary}

According to Søren Kierkegaard, the development of Christianity is a history of going away from it, or at least of mitigating the criteria of belonging to it. Dane proposes two models of the trans-confessional faith: (1) The recognition of the earthly life of Jesus Christ, of his death and resurrection, and nothing more. (2) The recognition of the faith as that which was defined above in the first point and, additionally, on this basis of the choice of the Bible, which is possible as the secondary act related to the faith but not as its starting point. Moreover, all the interpretations of the beyond-

43 Cyt. według wydania niemieckiego książki Waltera Lowrie, Das Leben Søren Kierkegaards, Düsseldorf-Köln 1955, s. 224-227. Por. także tłumaczenie książki Lowriego dokonane przez Aleksandra J. Prokopskiego pt. Kierkegaard, Kęty 2011, rozdział III pod tytułem „Alleluja!”, s. 605-610.

${ }^{44}$ Por. S. Kierkegaard, Okruchy filozoficzne. Chwila, tłum. K. Toeplitz, Kęty 2001, s. 184-192. 
confessional faith should be subjectively considered by a single individual. Kierkegaard mentions here some mystical elements. All the religious relationships should be personal in character. As far as the questions of faith and reason are concerned, the standpoint of Paulinism - either/or - is binding. Kierkegaard demands that the existing churches recognise themselves as representing the mitigated forms of Christianity; otherwise they have to undergo criticism. For him, the first two centuries of the existence of Christianity are the ideal ones, and the personal model is the „witness of the truth", of which he gives the detailed description. The increasing phenomenon of the trans-confessional faith has its roots in the civilisational changes (the secularization) as well as in the intensive manifestation, in the history of Christianity, of the practices which are inconsistent with the biblical background.

Keywords: faith; choice; subjectivity; criticism of all the existing confessions

Słowa kluczowe: wiara; wybór; subiektywizm; krytyka wszystkich istniejących wyznań

\section{BIBLIOGRAFIA}

Brandstaetter R., Krag biblijny, Warszawa 1979.

Broń-Wojciechowska A., N.F.S. Grundtvig, Warszawa 1986.

Bultmann R., Das Verhältnis der urchristlichen Christusbotschaft zum historischen Jesus, Bonn 1961.

Ferdek B., Błąd teologiczny a ekumenizm, w: Status błędu w filozofii i teologii, red. L. Miodoński, Wrocław 2014, s. 155-170.

Kierkegaard S., Czy biskup Mynster byt „, świadkiem prawdy”, jednym z „prawdziwych świadków prawdy” $i$ czy jest to prawda?, tłum. K. Toeplitz, „Kronos” 1 (2016), s. 223-227.

Kierkegaard S., Czy biskup Mynster byt „świadkiem prawdy”, jednym z „prawdziwych świadków prawdy” i czy jest to prawda??, w: Pisma późne, tłum. i komentarze K. Toeplitz, Kęty 2016, s. $350-357$.

Kierkegaard S., Nienaukowe zamykające „post scriptum” do „Okruchów filozoficznych”, thum., wstęp, komentarze K. Toeplitz, Kęty 2011.

Kierkegaard S., Okruchy filozoficzne. Chwila, thum K. Toeplitz, Kęty 2001.

Kierkegaard S., Okruchy filozoficzne. Chwila, thum. K. Toeplitz, Warszawa 1988.

Kłoczowski A., Drogi i bezdroża. Szkice z filozofii religii dla humanistów, Kraków 2017.

Kołakowski L., Świadomość religijna i więź kościelna. Studia nad chrześcijaństwem bezwyznaniowym XVII wieku, Warszawa 1965.

Pasek Z., Wyznania wiar. Protestantyzm, Kraków 1999.

Prokopski J.A., Paul Tillich - odwaga wiary w wieku zwątienia, „Nowa Krytyka” 36 (2016), s. 75-92.

Stasiak S., Btędy w przekazie tekstu biblijnego, w: Status błędu w filozofii i teologii, red. B. Ferdek, L. Miodoński, Wrocław 2014, s. 59-68.

Status błędu w filozofii i teologii, red. L. Miodoński, Wrocław 2014.

Toeplitz K., Czy sprzeczności moga mieć budujący charakter, „Słupskie Studia Filozoficzne” 4 (2002), s. 5-20.

Toeplitz K., Dlaczego Kierkegaard nie mógł uznać siebie za chrześcijanina, w: S. Kierkegaard, Pisma mniejsze (wybór) w thumaczeniu Karola Toeplitza, Toruń 2007, s. 5-10. 
Toeplitz K., Konflikt Abrahama (Próba egzystencjalizacji religii prawa), „Gdańskie Zeszyty Humanistyczne" 1966 z. 2, s. 29-71.

Toeplitz K., O immanentnych sprzecznościach w Biblii, w: Filozofia-dialog - uniwersalizm. Księga dedykowana prof. J. Kuczyńskiemu, red. J.L. Krakowiak, W. Lorenc, A. Miś, Warszawa, s. 67-77.

Toeplitz K., O możliwości lub niemożliwości istnienia chrześcijańskiego egzystencjalizmu, „Studia Filozoficzne" $1983 \mathrm{nr}$ 7, s. 3-26.

Toeplitz K., O tożsamości konfesyjnej, „Myśl Protestancka” cz. I 1999 nr 3, s. 20-36; cz. II 1999 nr, s. 32-43.

Toeplitz K., Wiara Sørena albo dlaczego Kierkegaard nie mógt się przyznać do bycia chrześcijaninem, w: W kręgu Kierkegaarda, red. A. Szwed, Kęty-Warszawa 2014, s. 3-12.

Wust P., Niepewność i ryzyko, thum. i wstęp K. Toeplitz, Warszawa 2006.

Wyznanie Augsburskie (Konfesja Augsburska), VII, O Kościele, w: Księgi Wyznaniowe Kościoła Luterańskiego, thum. A. Wantuła, J. Jackowski, W. Niemczyk, J. Pośpiech, Bielsko-Biała 1999, s. $144-145$.

KAROL TOEPLITZ - prof. dr hab., polski filozof, etyk i thumacz, wykładowca wielu uczelni; m.in. do 2009 roku na Wydziale Historyczno-Filozoficznym Akademii Pomorskiej w Słupsku oraz na Chrześcijańskiej Akademii Teologicznej w Warszawie. Był uczniem prof. Leszka Kołakowskiego. Profesor Toeplitz jest thumaczem na język polski prac wybitnego duńskiego filozofa, Sørena Kierkegaarda. Tłumaczył również z języka niemieckiego m.in. książkę Güntera Grassa. W obszarze zainteresowań profesora Toeplitza pozostają filozofia człowieka, filozofia religii, filozofia sztuki współczesnej, historia filozofii i teorii kultury, historia filozofii XIX i XX wieku oraz teorie kultury XX wieku. 